\title{
Landslide susceptibility mapping in the Beskid Niski Mts., Western Carpathians (Dukla commune, Poland)
}

\author{
Błażej BRONOWSKI ${ }^{1,{ }^{*}}$, Ryszard CHYBIORZ ${ }^{1}$ and Dominik JURA ${ }^{1}$ \\ 1 University of Silesia in Katowice, Faculty of Earth Sciences, Będzińska 60, 41-200 Sosnowiec, Poland
}

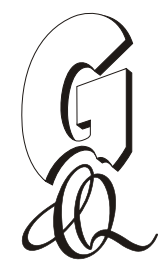

Bronowski, B., Chybiorz, R., Jura, D., 2016. Landslide susceptibility mapping in the Beskid Niski Mts., Western Carpathians (Dukla commune, Poland). Geological Quarterly, 60 (3): 586-596, doi: 10.7306/gq.1275

\begin{abstract}
Landslides are one of the most prominent processes degrading the Beskidy Mts. slopes. Susceptibility assessment is based on the detailed mapping of the Dukla commune $\left(235 \mathrm{~km}^{2}\right)$ at the scale 1:10,000 in frames of the project Landslide Counteracting System. The terrain affected by landslides is $19.59 \mathrm{~km}^{2}$, which is $8.34 \%$ of the researched area. The largest number of landslides can be found in the Beskid Dukielski Mts. area, where nearly $78 \%$ of all landslide areas are concentrated. Analysis of landslide-causing factors was performed using the index of entropy method. The following five factors were considered: lithology, slope inclination, slope aspect, distance to faults, and distance to drainage. The most important role in the development of mass movements in the study area is played by slope inclination $(0.0079)$ and lithology of siliciclastic flysch $(0.0066)$. The method applied also contributed to devising a landslide susceptibility map of considerable accuracy at $90.5 \%$. The analyses of the landslide factors have proven that understanding of geology and landforms is not only of cognitive significance, but adds to practical applications in spatial management. The studies confirmed usefulness of large-scale mapping of landslides and applying statistical methods and GIS techniques in the spatial analysis of landform transformations. The obtained landslide susceptibility map can be a basis for assessing landslide risk. High and very high landslide susceptibility classes cover nearly $50 \%$ of the study area.
\end{abstract}

Key words: landslide, susceptibility map, index of entropy, SOPO, Beskid Niski Mts.

\section{INTRODUCTION}

Siliciclastic flysch deposits of the Outer Carpathian Fold-and-Thrust Belt are particularly prone to intensive erosion processes and mass movements that cause a major local environmental hazard. In the Polish part of the Western Carpathian Mts., 39,464 landslides were mapped and 3090 terrains prone to mass movements were identified until April 2014 in an area of $12,474 \mathrm{~km}^{2}$ (Mrozek et al., 2014). The landslide density index $(L D I)$, i.e. ratio between the landslide area divided by the total area of the Beskidy Mts., fluctuates from 1 to $30 \%$ (Zabuski et al., 1999; Mrozek, 2013). One of the key factors in the development of landslides is the properties of flysch sediments. Indeed, alternating water-permeable (sandstones) and non-permeable (shales) layers facilitate this phenomenon.

The number of reactivated landslides has increased in the last 20 years. The main reasons responsible for the renewal are intense precipitation and groundwater fluctuations (Rączkowski and Mrozek, 2002; Wójcik et al., 2006; Starkel, 2006; Zabuski et. al., 2009). The slope stability is primarily affected by slope gradient (nearly $80 \%$ of all landslides in the study area are located on slopes inclined at $8-24^{\circ}$ ). In some cases, landslides

* Corresponding author, e-mail: blazejbronowski@wp.pl

Received: July 17, 2015; accepted: December 15, 2015; first published online: February 8, 2016 are the result of human interference as in the case of building, road or dam construction and extensive deforestation.

The losses due to landslide activity resulted from the fact that local authorities have not been conducting a proper register of areas apt to mass movements. In effect, multiple investments were set up in dangerous terrains. At present, identification of mass movements is conducted under the project "Landslide Counteracting System" (LCS)-SOPO (Grabowski et al., 2008; Mrozek et al., 2014). Furthermore, a more common access to digital reference and thematic data, as well as GIS software, enables morphometric and statistical analysis of landslides using small-scale methods. One of the methods, allowing for minimizing losses in the event of mass movements, is devising landslide susceptibility maps (Komac, 2012).

In Poland, the most commonly used methods for developing landslide susceptibility in the Beskidy Mts. include: the statistical index (Kamiński, 2007; Wojciechowski, 2008b; Długosz, 2011), the weights of evidence (Mrozek et al., 2004; Kamiński, 2012) and the empirical likelihood ratio (Mrozek, 2013). The current study is an attempt for constructing a map of landslide susceptibility, applying the statistical entropy index method that was used in mass movement assessments in other parts of the Carpathian Mts. (Vlcko et al., 1980; Jurko et al., 2006; Bednarik and Liscak, 2010; Constantin et al., 2011; Bednarik et al., 2012). This was the pioneering use of the method in landslide susceptibility mapping in the Beskidy Mts.

The primary goal of the study was to analyse the geological, geomorphic and hydrographic conditions contributing to the formation of landslides in the Beskid Niski Mts. and Jasło-Sanok 
Depression, as well as to mark out zones of increased susceptibility to the occurrence of landslides. Susceptibility assessment is based on detailed mapping $(1: 10,000)$ of the Dukla commune, performed as part of the LCS-SOPO project (Bardziński et al., 2013). Diverse geological structures (Dukla Nappe, Menilite and Hieroglyphic beds) and topography (low-mountain relief with foothills and valleys) of the study area makes it optimal testing ground for landslide analyses.

\section{STUDY AREA}

Dukla commune is located in the Beskid Niski Mts. and the Jasło-Sanok Depression, southeastern part of the Polish Carpathians (Fig. 1). The NW-SE orientation of mountain ridges enforces a rectangular drainage pattern (Zuchiewicz, 1990; Wójcik, 2003). The elevations of the area vary from $296 \mathrm{~m}$ a.s.I. in the Jasiołka Valley to $754 \mathrm{~m}$ a.s.l. at Baranie Mt. The slope gradient ranges from 3 to $60^{\circ}$, while the mean slope angle is $9.33^{\circ}$ (Table 1). The steeper slopes are located near Cergowa Mt. (716.4 m a.s.l.) and Kielanówka Mt. (559.8 $\mathrm{m}$ a.s.I.) in the Beskid Dukielski Mts. The mean slope angle for the Dukla Nappe area is $10.66^{\circ}$, whereas the Jasło-Sanok Depression slopes are more gradual $\left(6.95^{\circ}\right)$. The study area is dominated by slopes exposed toward the NE, E W and SW. The forests cover nearly $60 \%$ of the slopes. The average landslide index in the Beskid Niski Mts. was 2.6\% (Bober, 1984), however, its value can locally increase, particularly in the western part, even to 29.2\% (Mrozek et al., 2004; Mrozek, 2013), which leads up to 17 landslides/ $/ \mathrm{km}^{2}$ (Rączkowski, 2007).

Lithology of the Beskid Niski Mts. and Jasło-Sanok Depression is represented by flysch-type sediments of Cretaceous and Paleogene age (Fig. 1). In the Dukla commune these siliciclastics comprise the Silesian, Sub-Magura-Dukla and Magura successions. Fluvial sediments occur in valleys, and slopes are partly covered by Pleistocene and Holocene colluvial deposits (Cieszkowski et al., 1990; Wdowiarz et al., 1991; Jankowski and Kopciowski, 2009). The lithostratigraphic section of the Silesian Succession begins with the Eocene Variegated Shale and Hieroglyphic Beds (shales and sandstones). They are overlain by the Menilite Beds (Oligocene), which are composed mostly of dark brown shales with sandstones and cherts. Shales and sandstones of the Transition Beds grade upwards into the Oligocene Krosno Beds (Ślączka, 1971).

The Beskid Dukielski Mts. provide a stratotype section of transitional sediments between the Silesian and Magura successions, referred to as the Sub-Magura-Dukla succession. The Dukla Series comprises sandstones and shales of the Inoceramus Beds (Senonian-Paleocene) overlain by varie- gated and green shales and thin-bedded sandstones of the $\mathrm{Hi}-$ eroglyphic Beds of Paleocene-Eocene age (Fig. 1). The thick-bedded Mszanka Sandstones grade upwards into brown shales and marls of the Sub-Cergowa Beds (Oligocene). The upper section of the Dukla Series consists of medium-bedded Cergowa Sandstones and shales of the Menilite Beds. They are capped by medium-bedded sandstones and shales of the Krosno Beds. The flysch sediments of the Magura succession crop out in the southern part of the Dukla commune. They begin with the Inoceramus Beds, which comprise sandstones and shales with fucoid marls (Senonian-Paleocene). The Variegated Shales with sandstones (Eocene) grade upwards into the Sub-Magura Beds composed of marls, shales and sandstones. The Magura Beds (Oligocene) are represented by thick-bedded sandstones of the glauconitic facies. This flysch succession is terminated by the Supra-Magura Beds (Oligocene) that comprise shales, mudstones and medium-bedded sandstones (Kopciowski, 2009; Dirnerová et al., 2012).

The study area is dominated by a number of NNW-SSE striking fold-and-trust structures that are cut primarily by NNE-SSW oriented faults (Fig. 1). The Silesian Nappe contains the Bóbrka and Iwonicz anticlines inclined to the north. To the south it is in contact with strongly folded and thrust structures of the Dukla Nappe with the Cergowa Anticline, Piotrus Fold and flat Mszanka Syncline (Ślączka, 1971). The Silesian and Dukla nappes are heavily jointed (Mastella and Zuchiewicz, 2000) and cut by transverse faults, including the Jasiołka Fault. The Magura Nappe is characterized by numerous thrusts and slices. The Magura Thrust generally passes between the Sub-Magura and Krosno beds, rarely between the Mszanka Sandstones and Hieroglyphic Beds.

\section{MATERIALS AND METHODS}

Five passive factors were taken into account in the study of the effect of geological structure and landforms on the development of mass movement processes in the eastern part of the Beskid Niski Mts.: lithology $(L)$, tectonics $(F)$, slope inclination (I), slope aspect (A) and distance to drainage (D; Fig. 2). The parameters were subdivided into classes (e.g., a rock type or slope inclination class). The method applied for the spatial analysis and devising the landslide susceptibility map for the study area was the entropy index method (van Westen, 2004; Constantin et al., 2011; Bednarik et al., 2012; Pourghasemi et al., 2012). All lists, calculations and analyses included in the study were performed using ILWIS 3.7.2. GIS software.

Data on landslides were acquired during geological-cartographic works conducted in the study area in 2010-2012 as a

Area of landslide, landslide density index and morphometric parameters of the study area

\begin{tabular}{|c|c|c|c|c|c|c|}
\hline \multirow{2}{*}{ Area } & \multirow{2}{*}{$\begin{array}{l}\text { Total area } \\
{\left[\mathrm{km}^{2}\right]}\end{array}$} & \multirow{2}{*}{$\begin{array}{l}\text { Area of landside } \\
\qquad\left[\mathrm{km}^{2}\right]\end{array}$} & \multirow{2}{*}{$\begin{array}{l}\text { Landslide density index } \\
{[\%]}\end{array}$} & \multirow{2}{*}{$\frac{\text { Slope angle }\left[^{\circ}\right]}{\operatorname{Max}}$} & \multicolumn{2}{|c|}{ Slope aspect $\left[{ }^{\circ}\right]$} \\
\hline & & & & & Mean & Mean \\
\hline Study area & 235.02 & 19.59 & 8.34 & 60.20 & 9.33 & 171.91 \\
\hline Silesian Nappe & 67.99 & 2.43 & 3.57 & 49.50 & 6.95 & 178.10 \\
\hline Dukla Nappe & 114.71 & 15.31 & 13.35 & 60.20 & 10.66 & 174.58 \\
\hline Magura Nappe & 52.32 & 1.85 & 3.54 & 40.34 & 9.52 & 158.06 \\
\hline
\end{tabular}




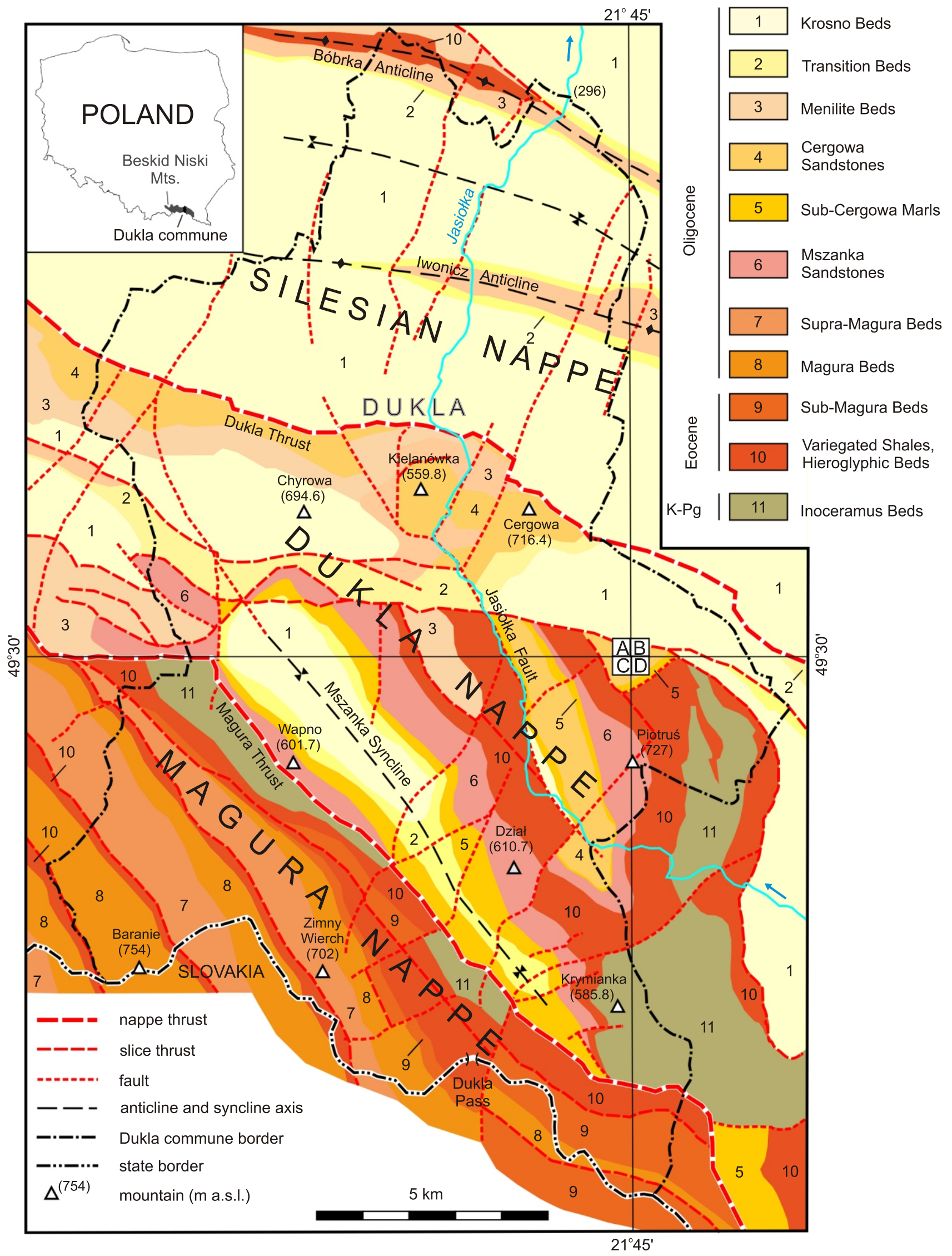

Fig. 1. Geological map of the Beskid Niski Mts. and Jasło-Sanok Depression in the Dukla commune

Map sheets: A - Jankowski and Kopciowski (2009); B - Wdowiarz et al. (1991); C - Kopciowski (2009); D - Cieszkowski et al. (1990); simplified, without Quaternary deposits; K-Pg - Senonian-Paleocene 
part of the SOPO program (Grabowski et al., 2008). The works consisted in mapping, identifying and documenting all landslides and terrains prone to mass movements on a map at the scale of 1:10,000 (Bardziński et al., 2013). The geological structure of the study area is based on the Detailed Geological Map of Poland at the scale of 1:50,000, verified during landslide mapping. The Digital Elevation Model at the scale of 1:10,000, offered by the Regional Center for Geodetic and Cartographic Documentation in Rzeszów, was used in analytical procedures According to Jura and Perski (2002), Wojciechowski (2008a) and Długosz (2012), the DEM is optimal for examining landslides due to its accuracy. Hydrographic data were sourced from the topographic maps at the scale of $1: 10,000$.

In this study, the weighting process is based on the methodology proposed by Vlcko et al. (1980). The index of entropy indicates the extent of disorder in the environment. This means that we can establish which of the passive factors examined in the study has the largest effect on the development of landslides. In detail, the entire process of calculation of weights is characterized by Bednarik and Liscak (2010) and Constantin et al (2011). The value of weight parameter $\left(W_{j}\right)$ characterizes the influence of a given factor on landslide occurrence (the higher the value, the greater the slope instability). Each thematic map is secondarily reclassified. Rank $(C)$ is based on the calculated probability density $\left(P_{i j}\right)$. After adding all the parameters [1], we obtain the landslide susceptibility map.

$$
L S I=\sum_{i=1}^{n} C \times W_{j}
$$

The map contains continuous data, and therefore, in order to simplify the illustration of differences in landslide susceptibility, the $L S /$ values are grouped into four susceptibility classes: low, moderate, high and very high. The classification method assumes that the landslide area within a higher susceptibility class is twice greater than the landslide area in the directly subordinate class (Long and De Smedt, 2012). Based on this rule, the expected percentages of observed landslide occurrences in the low, moderate, high and very high landslide susceptibility classes are 6.7, 13.3, 26.7 and 53.3\%, respectively (Fig. 3). To obtain the cut-off value corresponding to these percentages the cumulative percentage of observed landslide occurrence was plotted against the $L S /$ values.

Validation of the model was performed by applying a combination of the methods used by Clerici et al. (2006). At first, the landslide database was randomly split into two datasets. Out of 745 registered landslides, $521(70 \%)$ landslides were used to create a new model (LSZ map), while the remaining $224(30 \%)$ were used to verify the new landslide susceptibility map.

\section{CHARACTERISTICS OF THE LANDSLIDES}

Seven hundred and forty five landslides (Figs. 2A and 4) and 123 areas prone to mass movements were identified in the Dukla commune of $235 \mathrm{~km}^{2}$ in total (Bardziński et al., 2013). The landslides occupy $19.59 \mathrm{~km}^{2}$, which is $8.34 \%$ of the total area. This result exceeds those for the area obtained in earlier studies, which were $6.47 \%$ for the Dukla Nappe and $2.56 \%$ for the Magura Nappe (Bober, 1984). The results obtained from the survey indicate a clear increase in the area occupied by landslides, particularly in the Dukla Nappe, whose landslide density index was estimated for $13.35 \%$ (Table 1). This difference is mainly due to the detailed landslide mapping $(1: 10,000)$ performed as a part of the LCS-SOPO project. The level of activity of the landslides varies: 37 landslides are active, 338 are periodically active, 332 are inactive, and 38 display a mixed nature. The study area is dominated by small landslides up to $5,000 \mathrm{~m}^{2}$ $\left(0.005 \mathrm{~km}^{2}\right)$, which represent $32.35 \%$ of all landslides (Table 2 ). However, these landslides occupy only $2.32 \%$ of the area of all landslides. Landslides sized $0.01-0.025 \mathrm{~km}^{2}$ also account for a high proportion $-22.01 \%$. In contrast, the largest area is occupied by landslides of $>0.2 \mathrm{~km}^{2}$ and $0.05-0.1 \mathrm{~km}^{2}, 25.81 \%$ and $20.61 \%$, respectively. The largest landslide in the study area covers $1.2 \mathrm{~km}^{2}$.

In the northern part of the Dukla commune, in the Jasło-Sanok Depression of $67.99 \mathrm{~km}^{2}$, there are 190 inactive landslides covering up to $2 \mathrm{~km}^{2}(L D I=3.57 \%)$. The area of Bóbrka and Iwonicz anticlinal ridges of $25 \mathrm{~km}^{2}$ is dominated by consequent small landslides of up to $0.005 \mathrm{~km}^{2}$ in area (78\%), and medium landslides up to $0.025 \mathrm{~km}^{2}(20 \%)$. The landslides include weathering rocks and colluvium resting on thin-bedded sandstones and shales of the Krosno Beds of the Silesian Succession $(L D I=2.4 \%)$ or the Transition Beds $(L D I=8.3 \%)$ and the Menilite Beds $(L D I=9.7 \%)$. The landslides group on afforested valley slopes.

In the Dukla Nappe area of $114.71 \mathrm{~km}^{2}$, there are nearly 500 landslides, out of which $10 \%$ are active. To the west of the Jasiołka Valley, 320 landslides were indentified on the outcrops of the Cergowa Sandstones, which are inclined at $20-30^{\circ}$ toward the SSW. The eastern slopes of the Jasiołka Valley are formed by numerous large-scale landslides developed on the Variegated Shale and Hieroglyphic Beds. These obsequent landslides constitute a major threat to the Dukla Pass road and the designed reservoir on the Jasiołka River (Zabuski et al., 1999). The northern slope of Cergowa Mt. $\left(4 \mathrm{~km}^{2}\right)$ reflects the front of the Dukla Nappe, marked by 13 obsequent landslides of $1.8 \mathrm{~km}^{2}$ in total area $(L D I=45 \%)$. Rock falls (up to $3 \mathrm{~m}$ across) of the Cergowa Sandstones were also identified in the colluvium. Furthermore, peat was found in trenches at the foot of Cergowa Mt., the age of which was estimated for approximately $4,820 \pm 70$ years B.P. (Szczepanek, 2001). The landslides occurring on the slopes between Cergowa Mt. and Kielanówka Mt. pose a threat, among others, to the newly designed Dukla town bypass road and the dam in the gorge of the Jasiołka Valley (Zabuski et al., 1999). On the southern slope of Cergowa Mt. $\left(15 \mathrm{~km}^{2}\right), 30$ major consequent landslides contain blocks (up to $25 \mathrm{~m}$ ) of the Cergowa Sandstones, split by numerous fissures and caves of Holocene age (Urban et al., 2007). One the most dangerous landslide is located on the eastern slope of Kielanówka Mt. Its triggering mechanisms included human activity (quarry) and earthquake (Gerlach et al., 1958).

Large landslides up to $0.36 \mathrm{~km}^{2}$ and non-karst caves were identified on Piotruś Mt. Its slope, inclined at an angle of $25^{\circ}$ to

Table 2

Area classes, size and number of landslides in the study area

\begin{tabular}{|l|c|c|c|c|}
\hline \multirow{2}{*}{$\begin{array}{c}\text { Area class } \\
{\left[\mathrm{km}^{2}\right]}\end{array}$} & $\begin{array}{c}\text { Landslide } \\
\text { area } \\
{\left[\mathrm{km}^{2}\right]}\end{array}$ & \multicolumn{3}{|c|}{ Number of landslides } \\
\cline { 3 - 5 } & 0.46 & 2.32 & 241 & 32.35 \\
\hline$<0.005$ & 0.89 & 4.55 & 130 & 17.45 \\
\hline $0.005-0.01$ & 0.43 & 12.41 & 164 & 22.01 \\
\hline $0.01-0.025$ & 2.43 & 17.90 & 108 & 14.50 \\
\hline $0.025-0.05$ & 3.5 & 20.61 & 63 & 8.46 \\
\hline $0.05-0.1$ & 4.04 & 16.40 & 26 & 3.49 \\
\hline $0.1-0.2$ & 3.21 & 25.81 & 13 & 1.74 \\
\hline$>0.2$ & 5.06 & 100 & 745 & 100 \\
\hline Total & 19.59 & &
\end{tabular}



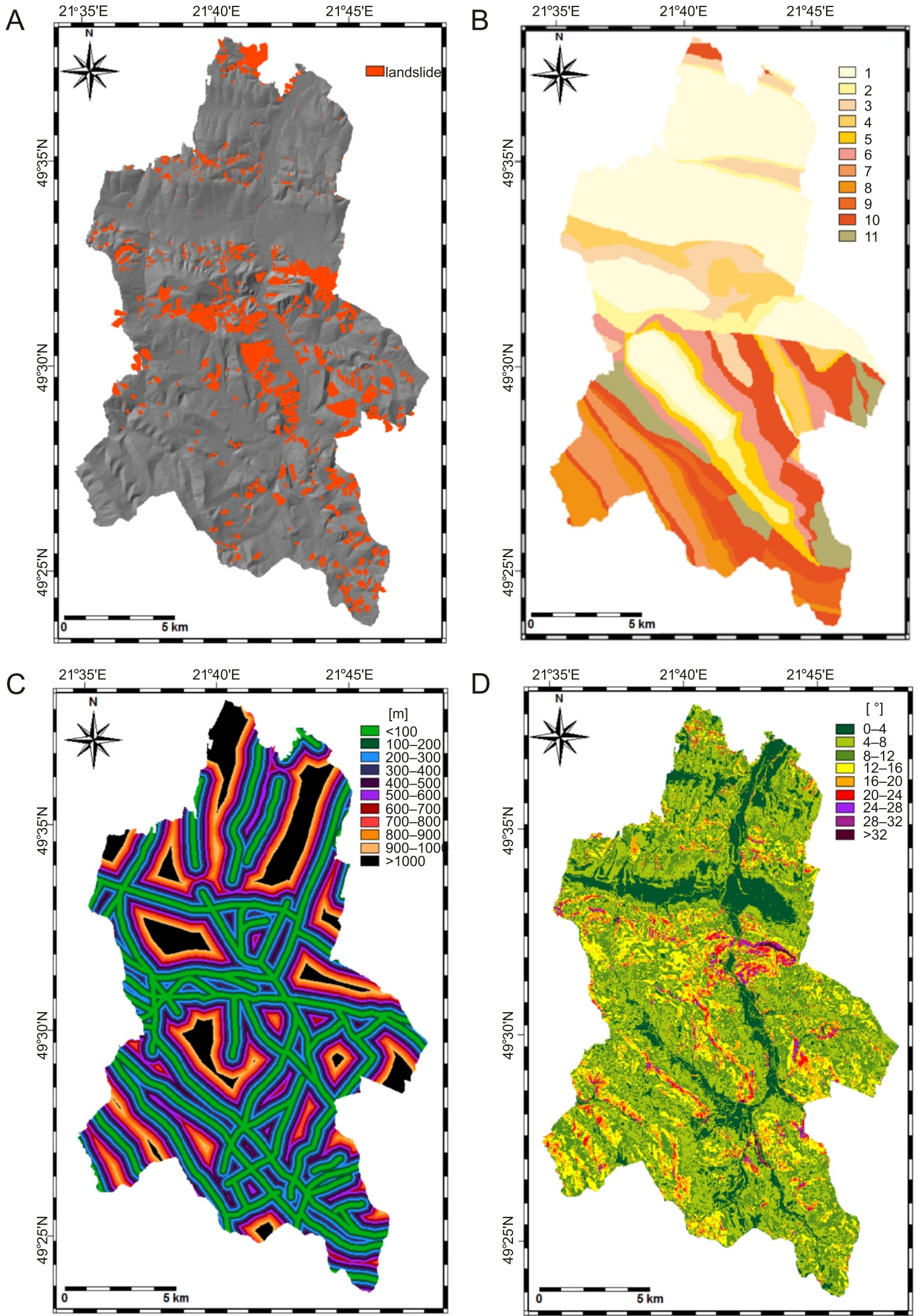

Fig. 2. Thematic maps of Dukla commune

A - landslide inventory map (DEM), B - lithological units (explanations as in Fig. 1), C - distance to faults, D - slope angle (DEM) 

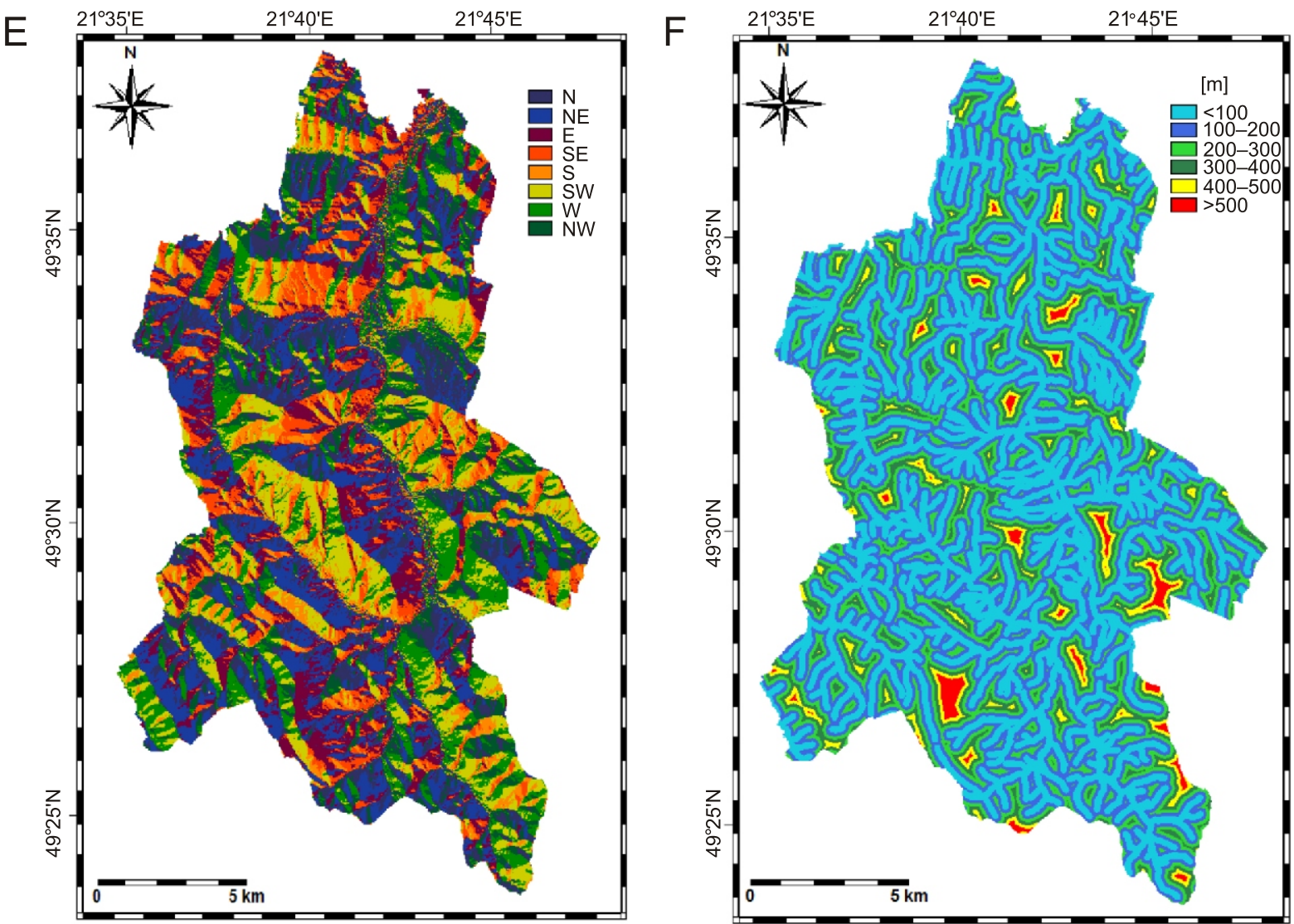

Fig. 2. Thematic maps of Dukla commune (cont.)

$\mathbf{E}$ - slope aspect (DEM), $\mathbf{F}$ - idstance to drainage

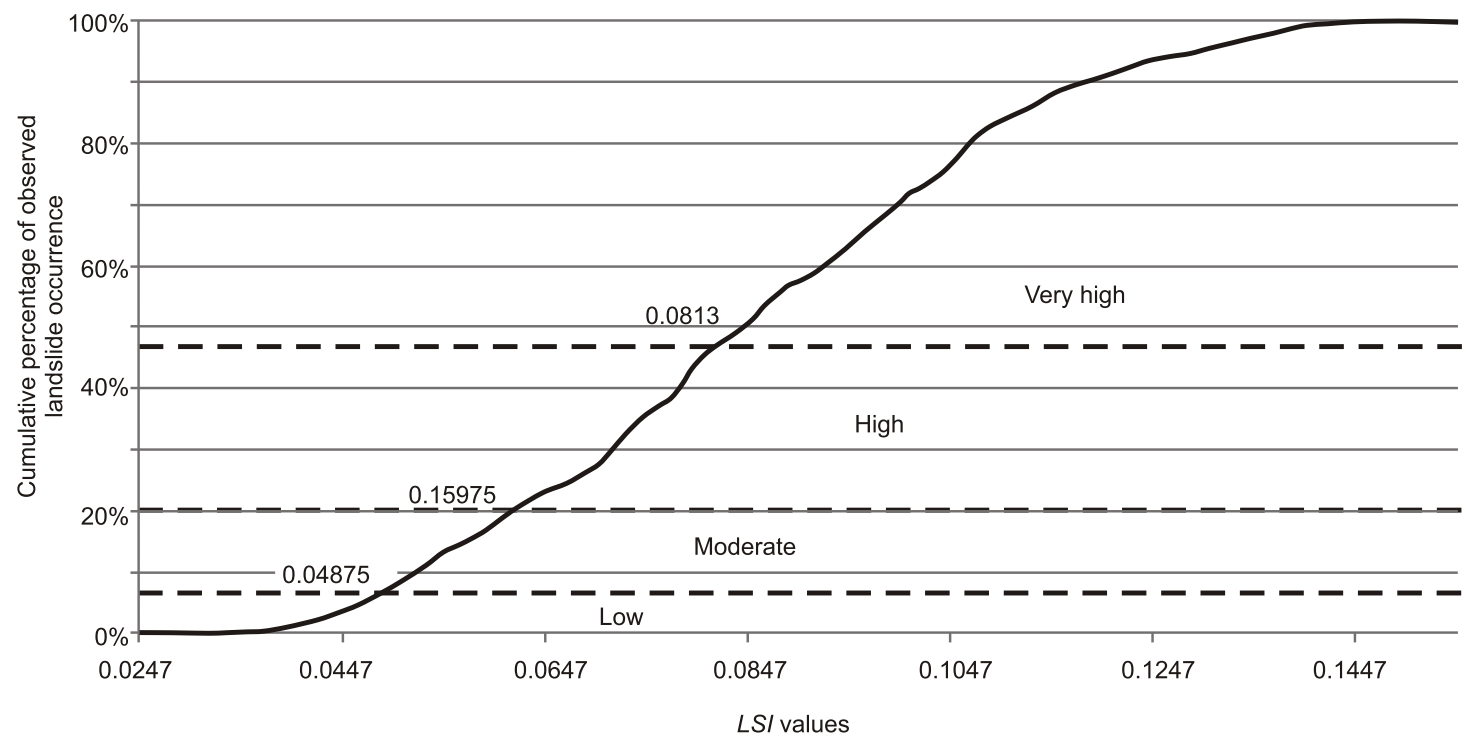

Fig. 3. Cumulative percentage of observed landslides versus ranked $L S /$ value, and derivation of cutoff values to identify landslide susceptibility classes 


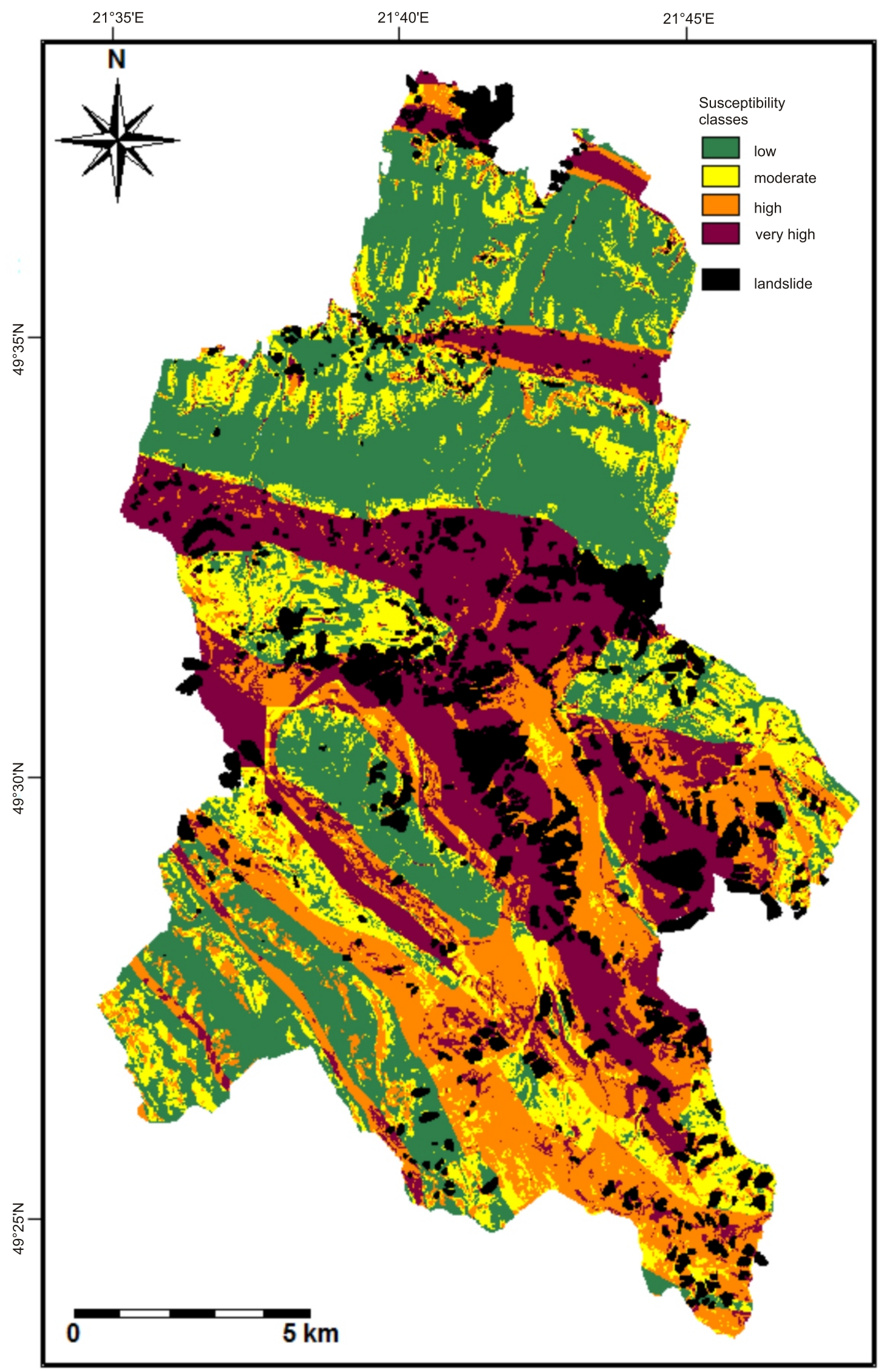

Fig. 4. The landslide susceptibility zonation (LSZ) map of Dukla commune 
the west, is formed by subsequent slides of colluvium with blocks of the Mszanka Sandstones and Hieroglyphic Beds. The primary features of these landslides are numerous trenches, fissures and caves (up to 5 transverse cracks per landslide). In the southern part of the Beskid Dukielski Mts., 60 landslides of about $3.15 \mathrm{~km}^{2}$ in total area were identified in the area of $21 \mathrm{~km}^{2}$ $(L D I=15 \%)$. The slopes are overgrown with beech and fir forests up to 100 years old (nearly $90 \%$ of this area is afforested), and thus will pose a higher landslide threat after the forest is logged or wind-felled.

Sixty landslides, each up to $0.025 \mathrm{~km}^{2}$ in area, were identified to the north-west of Dukla Pass, on the outcrops of sandstones and shales of the Magura succession (Figs. 1 and 4). On the area of $52.32 \mathrm{~km}^{2}$, these landslides constitute $3.54 \%$ of the area and are primarily developed in the lower parts of the slopes. Moreover, landslide susceptibility is further increased by cracks and faults, as well as fold-and-thrust deformations of the Magura Nappe rocks with numerous slices. The landslide threat in afforested areas, not intended for agricultural purposes, is low.

\section{FACTORS AND LANDSLIDE SUSCCEPTIBILITY MAP}

The analysis of $W_{j}$ values for the considered landslide causal factors has indicated that the slope inclination (0.0079) and the lithology of the slope (0.0066) are the most significant factors in the mass movement process in the study area ( $\mathrm{Ta}$ ble 3). As regards the slope inclination, the landslide occurrence density $-P_{i j}$ grows proportionally to the inclination angle, recording the highest values for $>32^{\circ}(0.22)$ and $28-32^{\circ}(0.18)$. However, the largest number of landslides occur on slopes with inclination angles from 8 to $16^{\circ}\left(10.92 \mathrm{~km}^{2}\right)$, which is $56 \%$ of the entire landslide area. This corresponds to the results obtained in the western part of the Beskid Niski Mts. (Mrozek, 2013), Beskid Żywiecki Mts. (Wójcik, 1997), Dynowskie Foothills (Wójcik and Zimnal, 1996; Kamiński, 2007), and in the Sibiciu Basin (Constantin et al., 2011). As regards the lithology, the most susceptible formations include the Menilite Beds, Mszanka and Cergowa Sandstones, Transition Beds, Variegated Shales and Hieroglyphic Beds, for which the $P_{i j}$ values are $0.18,0.15,0.14$ and 0.13 , respectively. This means that sandstones and shales are equally susceptible to mass movements, particularly the interface between both members. The susceptibility of the Mszanka Sandstones results from the fact that the underlying shales are very distorted, which leads to the formation of large landslides.

Nearly $70 \%$ of all landslides in the study area are located within $200 \mathrm{~m}$ from a watercourse $\left(13.41 \mathrm{~km}^{2}\right)$. This could be due to the fact that streams affect stability by eroding and undercutting the slopes. As regards the distance to faults, the landslide density drops proportionally to the distance, apart from a slight increase in the 600-800 $\mathrm{m}$ area, which is, however, followed by a gradual decrease (Table 3). The $P_{i j}$ values for $0-100 \mathrm{~m}$, 100-200 m, 200-300 $\mathrm{m}$ and 700-800 $\mathrm{m}$ are 0.1, 0.1, 0.09 and 0.09 , respectively. Climatic conditions are in close correlation with the slope aspect. However, slope exposition (0.0003) has the least effect on landslide susceptibility in the research area. The landslide occurrence density value for individual classes is almost identical, fluctuating between 0.7 and 0.10 . The landslide susceptibility map was constructed by multiplying the calculated parameter weight by the rank assigned to the class during reclassification [2]:

$$
\begin{gathered}
L S I=0.0079 \times I_{\text {rank }}+0.0066 \times L_{\text {rank }}+0.0010 \times D_{\text {rank }}+[2] \\
0.0006 \times F_{\text {rank }}+0.0003 \times A_{\text {rank }}
\end{gathered}
$$

\begin{tabular}{|c|c|c|c|c|c|c|c|c|c|c|}
\hline \multirow[b]{2}{*}{ Factor } & \multirow[b]{2}{*}{ Class } & $\begin{array}{l}\text { Total } \\
\text { area }\end{array}$ & $\begin{array}{l}\text { Land- } \\
\text { slide } \\
\text { area }\end{array}$ & $\begin{array}{l}\text { Land- } \\
\text { slide oc- } \\
\text { currence } \\
\text { density }\end{array}$ & $\begin{array}{l}\text { Proba- } \\
\text { bility } \\
\text { density }\end{array}$ & Entropy & $\begin{array}{l}\text { Maxi- } \\
\text { mum } \\
\text { entropy }\end{array}$ & $\begin{array}{l}\text { Information } \\
\text { coefficient }\end{array}$ & $\begin{array}{l}\text { Weight } \\
\text { value }\end{array}$ & \multirow[b]{2}{*}{ Rank } \\
\hline & & $\begin{array}{c}A_{t} \\
{\left[\mathrm{~km}^{2}\right]}\end{array}$ & $\begin{array}{l}\mathrm{A}_{\mathrm{sd}} \\
{\left[\mathrm{km}^{2}\right]}\end{array}$ & $\begin{array}{c}P_{i j} \\
\left(\frac{A_{s d}}{A_{t}}\right)\end{array}$ & $\begin{array}{l}\left(P_{i j}\right) \\
\frac{P_{i j}}{\sum_{i}^{S_{i}} P_{i j}}\end{array}$ & $\left(-\sum_{i=1}^{S_{i}}\left(P_{i j}\right) \log _{2}\left(P_{i j}\right)\right)$ & $\begin{array}{c}H_{j \max } \\
\left(\log _{2} S_{j}\right)\end{array}$ & $\left(\frac{H_{j \max }-H_{j}}{H_{j \max }}\right)$ & $\begin{array}{c}W_{j} \\
\left(I_{j} \times P_{i j_{\text {avg }}}\right)\end{array}$ & \\
\hline $\begin{array}{l}\text { Litho- } \\
\text { logy }\end{array}$ & & & & & & 3.22 & 3.46 & 0.070 & 0.0066 & \\
\hline & Krosno Beds & 86.8 & 3.51 & 0.04 & 0.04 & & & & & 3 \\
\hline & Transition Beds & 15.4 & 2.08 & 0.13 & 0.13 & & & & & 8 \\
\hline & Menilite Beds & 16.1 & 2.85 & 0.18 & 0.17 & & & & & 11 \\
\hline & Cergowa Sandstones & 15.4 & 2.08 & 0.14 & 0.13 & & & & & 9 \\
\hline & Sub-Cergowa Marls & 11.3 & 0.86 & 0.08 & 0.07 & & & & & 5 \\
\hline & Mszanka Sandstones & 14.7 & 2.19 & 0.15 & 0.14 & & & & & 10 \\
\hline & Supra-Magura Beds & 11.8 & 0.19 & 0.02 & 0.02 & & & & & 1 \\
\hline & Magura Beds & 12.6 & 0.29 & 0.02 & 0.02 & & & & & 2 \\
\hline & Sub-Magura Beds & 6.7 & 0.62 & 0.09 & 0.09 & & & & & 6 \\
\hline & $\begin{array}{l}\text { Variegated Shales, } \\
\text { Hieroglyphic Beds }\end{array}$ & 32.1 & 4.08 & 0.13 & 0.12 & & & & & 7 \\
\hline & Inoceramus Beds & 12.0 & 0.86 & 0.07 & 0.07 & & & & & 4 \\
\hline & Total & 235.0 & 19.59 & 1.04 & & & & & & \\
\hline
\end{tabular}

Spatial relationship between each conditioning factor and landslides by index of entropy 
Tab. 3 cont

\begin{tabular}{|c|c|c|c|c|c|c|c|c|c|c|}
\hline \multirow[b]{2}{*}{ Factor } & \multirow[b]{2}{*}{ Class } & $\begin{array}{l}\text { Total } \\
\text { area }\end{array}$ & $\begin{array}{l}\text { Land- } \\
\text { slide } \\
\text { area }\end{array}$ & $\begin{array}{l}\text { Land- } \\
\text { slide oc- } \\
\text { currence } \\
\text { density } \\
\end{array}$ & $\begin{array}{l}\text { Proba- } \\
\text { bility } \\
\text { density }\end{array}$ & \multirow[b]{2}{*}{$\left(-\sum_{i=1}^{S_{i}}\left(P_{i j}\right) \log _{2}\left(P_{i j}\right)\right)$} & $\begin{array}{l}\text { Maxi- } \\
\text { mum } \\
\text { entropy }\end{array}$ & $\begin{array}{l}\text { Information } \\
\text { coefficient }\end{array}$ & $\begin{array}{l}\text { Weight } \\
\text { value }\end{array}$ & \\
\hline & & $\begin{array}{c}\mathrm{A}_{\mathrm{t}} \\
{\left[\mathrm{km}^{2}\right]}\end{array}$ & $\begin{array}{l}\mathrm{A}_{\mathrm{sd}} \\
{\left[\mathrm{km}^{2}\right]}\end{array}$ & $\left(\frac{P_{i j}}{A_{t}}\right)$ & $\left(\begin{array}{c}\left(P_{i j}\right) \\
\frac{P_{i j}}{\sum_{j=1}^{S_{i}} P_{i j}}\end{array}\right)$ & & $\begin{array}{c}H_{\text {jmax }} \\
\left(\log _{2} S_{j}\right)\end{array}$ & $\left(\frac{H_{j \max }-H_{j}}{H_{j \max }}\right)$ & $\begin{array}{c}W_{j} \\
\left(I_{j} \times P_{i j_{\text {avg }}}\right)\end{array}$ & Rank \\
\hline \multirow[t]{8}{*}{$\begin{array}{l}\text { Dis- } \\
\text { tance } \\
\text { to } \\
\text { drain- } \\
\text { age }\end{array}$} & & & & & & 2.56 & 2.59 & 0.011 & 0.0010 & \\
\hline & $0-100 \mathrm{~m}$ & 91.8 & 7.68 & 0.08 & 0.15 & & & & & 3 \\
\hline & $100-200 \mathrm{~m}$ & 71.0 & 5.73 & 0.08 & 0.15 & & & & & 1 \\
\hline & $200-300 \mathrm{~m}$ & 41.1 & 3.34 & 0.08 & 0.15 & & & & & 2 \\
\hline & $300-400 \mathrm{~m}$ & 20.6 & 1.81 & 0.09 & 0.16 & & & & & 5 \\
\hline & $400-500 \mathrm{~m}$ & 7.7 & 0.66 & 0.09 & 0.15 & & & & & 4 \\
\hline & $>500 \mathrm{~m}$ & 2.8 & 0.37 & 0.14 & 0.24 & & & & & 6 \\
\hline & Total & 235.0 & 19.59 & 0.55 & & & & & & \\
\hline \multirow[t]{11}{*}{$\begin{array}{l}\text { Slope } \\
\text { angle }\end{array}$} & & & & & & 2.98 & 3.17 & 0.061 & 0.0079 & \\
\hline & $0-4^{\circ}$ & 38.5 & 0.56 & 0.01 & 0.01 & & & & & 1 \\
\hline & $4-8^{\circ}$ & 69.1 & 3.85 & 0.06 & 0.05 & & & & & 2 \\
\hline & $8-12^{\circ}$ & 63.1 & 6.36 & 0.10 & 0.09 & & & & & 3 \\
\hline & $12-16^{\circ}$ & 37.7 & 4.56 & 0.12 & 0.10 & & & & & 4 \\
\hline & $16-20^{\circ}$ & 16.2 & 2.58 & 0.16 & 0.14 & & & & & 7 \\
\hline & $20-24^{\circ}$ & 6.5 & 1.02 & 0.16 & 0.14 & & & & & 5 \\
\hline & $24-28^{\circ}$ & 2.4 & 0.38 & 0.16 & 0.14 & & & & & 6 \\
\hline & $28-32^{\circ}$ & 0.9 & 0.16 & 0.18 & 0.15 & & & & & 8 \\
\hline & $>32^{\circ}$ & 0.6 & 0.13 & 0.22 & 0.19 & & & & & 9 \\
\hline & Total & 235.0 & 19.59 & 1.16 & & & & & & \\
\hline \multirow[t]{10}{*}{$\begin{array}{l}\text { Slope } \\
\text { aspect }\end{array}$} & & & & & & 2.99 & 3.00 & 0.004 & 0.0003 & \\
\hline & $\mathrm{N}$ & 30.6 & 2.91 & 0.09 & 0.14 & & & & & 7 \\
\hline & $\mathrm{NE}$ & 41.9 & 3.34 & 0.08 & 0.12 & & & & & 3 \\
\hline & $E$ & 32.2 & 2.88 & 0.09 & 0.13 & & & & & 6 \\
\hline & SE & 22.1 & 2.25 & 0.10 & 0.15 & & & & & 8 \\
\hline & $S$ & 20.0 & 1.62 & 0.08 & 0.12 & & & & & 4 \\
\hline & SW & 31.1 & 2.17 & 0.07 & 0.10 & & & & & 1 \\
\hline & W & 31.9 & 2.59 & 0.08 & 0.12 & & & & & 5 \\
\hline & NW & 25.2 & 1.84 & 0.07 & 0.11 & & & & & 2 \\
\hline & Total & 235.0 & 19.59 & 0.67 & & & & & & \\
\hline \multirow[t]{13}{*}{$\begin{array}{c}\text { Dis- } \\
\text { tance } \\
\text { to } \\
\text { faults } \\
\end{array}$} & & & & & & 3.43 & 3.46 & 0.008 & 0.0006 & \\
\hline & $0-100 \mathrm{~m}$ & 39.2 & 3.80 & 0.10 & 0.11 & & & & & 11 \\
\hline & $100-200 \mathrm{~m}$ & 36.3 & 3.61 & 0.10 & 0.11 & & & & & 10 \\
\hline & $200-300 \mathrm{~m}$ & 31.1 & 2.83 & 0.09 & 0.10 & & & & & 9 \\
\hline & $300-400 \mathrm{~m}$ & 26.0 & 2.14 & 0.08 & 0.09 & & & & & 7 \\
\hline & $400-500 \mathrm{~m}$ & 21.1 & 1.71 & 0.08 & 0.09 & & & & & 6 \\
\hline & $500-600 \mathrm{~m}$ & 17.5 & 1.21 & 0.07 & 0.08 & & & & & 3 \\
\hline & $600-700 \mathrm{~m}$ & 14.1 & 1.10 & 0.08 & 0.09 & & & & & 5 \\
\hline & $700-800 \mathrm{~m}$ & 12.1 & 1.05 & 0.09 & 0.10 & & & & & 8 \\
\hline & $800-900 \mathrm{~m}$ & 9.8 & 0.72 & 0.07 & 0.08 & & & & & 4 \\
\hline & $900-1000 \mathrm{~m}$ & 8.1 & 0.55 & 0.07 & 0.08 & & & & & 2 \\
\hline & $>1000 \mathrm{~m}$ & 19.7 & 0.89 & 0.04 & 0.05 & & & & & 1 \\
\hline & Total & 235.0 & 19.59 & 0.87 & & & & & & \\
\hline
\end{tabular}


According to the landslide susceptibility map (Fig. 4), classes corresponding to high and very high landslide susceptibility cover nearly $50 \%$ of the area, mostly in the Beskid Dukielski Mts., in the vicinity of Cergowa Mt. and Chyrowa Mt. (Fig. 1). This results from steep slopes and the lithology (Menilite Beds, Mszanka Sandstones, Cergowa Sandstones). Approximately $70 \%$ of the Dukla Nappe area is situated within the very high or high susceptibility zones. One of the key factors in these valleys is bank erosion. In the Silesian Nappe area, with gradual slopes and composed almost exclusively of the Krosno Beds, landslides are less frequent. Nearly $65 \%$ of the area is assigned to the low landslide susceptibility class, which is $32 \%$ of the overall area.

All the weights of parameters calculated using the entropy index method for $70 \%$ of all landslides show similar values. $\mathrm{Li}-$ thology and slope inclination are still the most decisive factors, however, they have switched positions [3]. Now, it is lithology with its $W_{j}$ value $(0.0052)$ which has the greatest effect on the formation of landslides. As regards the distance to drainage, the effect of this parameter has increased to reach the value (0.0021). No significant changes were recorded for the remaining factors. The validation map was drawn up according to the following formula:

$$
\begin{gathered}
L S I=0.0052 \times L_{\text {rank }}+0.0046 \times I_{\text {rank }}+0.0021 \times D_{\text {rank }}+[3] \\
0.0005 \times F_{\text {rank }}+0.0002 \times A_{\text {rank }}
\end{gathered}
$$

The index of entropy was applied for several studies in the Carpathians (Bednarik et al., 2009, 2012; Constantin et al., 2011) and the success of this methodology varies. In order to verify the accuracy of the model, the new landslide susceptibility map was compared to 221 landslides. If even a part of a landslide was located in the high or very high susceptibility class, the landslide was recognized as well marked. Two hundred landslides were correctly marked, leaving 21 predicted incorrectly. In order to verify the correctness of the model, a correlation matrix was created between a model including 100\% landslides and a model including $70 \%$ landslides. Considering the high percentage of correctly marked landslides $(90.5 \%)$ and a strong correlation between the two landslide susceptibility maps, we can claim that the validation process was successfully com- pleted. High accuracy of the method results from similar-scale input data (DEM, topographic maps, landslide inventory maps $10,000)$ and verification of the geology during field landslide mapping. As various methods (bivariate and multivariate) have been used for mass movement mapping in the Beskidy Mts., further studies should include comparative analysis between those methods.

\section{CONCLUSIONS}

Analysis of the index of entropy for landslide susceptibility mapping of the Beskid Niski Mts. and Jasło-Sanok Depression revealed that the main landslide causal factors are (1) slope inclination angle and (2) lithology of flysch rocks. In contrast, factors like distance to faults and slope aspect have the least effect on landslide susceptibility in the study area. A strong relationship between slope angle and lithology has been found. Most of the landslides develop on the Menillite Beds, Variegated Shales and Hieroglyphic Beds on slopes inclined from 8 to $16^{\circ}$. In the final landslide susceptibility map, the high class occupies an area of $52.79 \mathrm{~km}^{2}$, while the very high class $-63.53 \mathrm{~km}^{2}$. Majority of that highly landslide susceptible area is situated in the Dukla Nappe, where slopes are extremely prone to forming new landslides and rejuvenating old ones. This study considers only passive factors causing landslides, omitting active ones. One of the main triggering factors is rainfall. Further studies on landslides in the Beskidy Mts. should include this factor.

The model performed well, as the resultant landslide susceptibility map has the high landslide prediction accuracy $(90.5 \%)$. This verifies that application of the methodology is effective in mass movement studies in the Beskidy Mts. The landslide susceptibility map constructed by using the index of entropy may be useful for land management and area development plans for communes and cities affected by landslides. The map can be also used by local authorities for registration areas prone to mass movement.

Acknowledgements. We would like to thank the reviewers of this paper: Dr. M. Bednarik and Prof. A. Wójcik for constructive comments. This work was supported by the Faculty of Earth Sciences, University of Silesia in Katowice.

\section{REFERENCES}

Bardziński, W., Chybiorz, R., Jura, D., Kuzak, R., Lewandowski, J., Malik, K., 2013. Mapa osuwisk i terenów zagrożonych ruchami masowymi w skali 1:10 000, gmina Dukla, pow. krośnieński, woj. podkarpackie. http://geoportal.pgi.gov.pl/portal/page/portal/SOPO

Bednarik, M., Liscak, P., 2010. Landslide susceptibility assessment in Slovakia. Mineralia Slovaca, 42: 193-204.

Bednarik, M., Magulova, B., Matys, M., Marschalko, M., 2009 Landslide susceptibility assessment of the Kralovany-Liptovsky Mikulas railway case study. Physics and chemistry of the Earth, PartsA/B/C, 35: 162-171.

Bednarik, M., Yilmaz, I., Marschalko, M., 2012. Landslide hazard and risk assessment: a case study from the Hlohovec-Sered landslide area in south-west Slovakia. Natural Hazards, 64 547-575.

Bober, L., 1984. Landslide areas in the Polish flysch Carpathians and their connection with the geological structure of the region (in Polish with English summary). Biuletyn Instytutu Geologicznego, 340: 115-161.

Cieszkowski, M., Ślączka, A., Zuchiewicz, W., 1990. Detailed Geological Map of Poland, scale 1:50 000, sheet Jaśliska (1056) (in Polish). Państwowy Instytut Geologiczny, Warszawa. http://bazagis.pgi.gov.pl/website/cbdg/viewer.htm

Clerici, A., Perego, S., Tellini, C., Vescovi, P., 2006. A GIS-based automated procedure for landslide susceptibility mapping by the conditional analysis method: the Baganza valley case study (Italian, Northern Apennines). Environmental Geology, 50: 941-961.

Constantin, M., Bednarik, M., Jurchescu, M.C., Vlaicu, M., 2011. Landslide susceptibility assessment using the bivariate statistical analysis and the index of entropy in the Sibiciu Basin (Romania). Environmental Earth Sciences, 63: 397-406.

Dirnerová, D., Prekopová, M. and Janočko, J., 2012. Sedimentary record of the Dukla Basin (Outer Carpathians, Slovakia and 
Poland) and its implications for basin evolution. Geological Quarterly, 56 (3): 547-560.

Długosz, M., 2011. Landslide susceptibility assessment in the different regions of the Polish Carpathians. Studia Geomorphologica Carpatho-Balcanica, 45: 25-46.

Długosz, M., 2012. Digital Terrain Model (DTM) as a tool for landslide investigation in the Polish Carpathians. Studia Geomorphologica Carpatho-Balcanica, 46: 5-23.

Gerlach, T., Pokorny, J., Wolnik, R., 1958. The landslide at Lipowica (in Polish with English summary). Przegląd Geograficzny, 30: 685-700.

Grabowski, D., Marciniec, P., Mrozek, T., Nescieruk, P., Rączkowski, W., Wójcik, A., Zimnal, Z., 2008. Instrukcja opracowania Mapy osuwisk i terenów zagrożonych ruchami masowymi. Państwowy Instytut Geologiczny, Warszawa.

Jankowski, L., Kopciowski, R., 2009. Detailed Geological Map of Poland, scale 1:50 000, sheet Nowy Żmigród (1039) (in Polish). Państwowy Instytut Geologiczny (in print).

Jura, D., Perski, Z., 2002. Delineation of Landslides in the Carpathians using InSAR DTM. In: Landslides (eds. J. Ciesielczuk and S. Ostaficzuk): 95-101. Mineral and Energy Economy Research Inst. of Polish Academy of Science, Kraków.

Jurko, J., Paudits, P., VIcko, J., 2006. Landslide susceptibility map of Liptovska kotlina Basin using GIS. IAEG2006, Nottingham, United Kingdom: 1-7. http://iaeg2006.geolsoc.org.uk/cd/PAPERS/IAEG_162.PDF

Kamiński, M., 2007. Landslide susceptibility map: a case study from the Jodłówka region (Dynowskie Foothills) (in Polish with English summary). Przegląd Geologiczny, 55: 779-784.

Kamiński, M. 2012. Landslide susceptibility map in a regional scale - example from of San valley in the Dynów Foothills (in Polish with English summary). Biuletyn Państwowego Instytutu Geologicznego, 452: 109-118.

Komac, M., 2012. Regional landslide susceptibility model using the Monte Carlo approach - the case of Slovenia. Geological Quarterly, 55 (1): 41-54.

Kopciowski, R., 2009. Detailed Geological Map of Poland, scale 1:50 000, sheet Tylawa (1055) (in Polish). Państwowy Instytut Geologiczny (in print).

Long, N.T., De Smedt, F., 2012. Application of an analytical hierarchical process approach for landslide susceptibility mapping in A Luoi district, Thua Thien Hue Province, Vietnam. Environmental Earth Sciences, 66: 1739-1752.

Mastella, L., Zuchiewicz, W., 2000. Jointing in the Dukla Nappe (Outher Carpathians, Poland): an attempt at palaeostress reconstruction. Geological Quarterly, 44 (4): 377-390.

Mrozek, T., 2013. Landslide hazard and risk for a case-study of Szymbark region (Beskid Niski Mts.) (in Polish with English summary). Prace Państwowego Instytutu Geologicznego, 199: $1-40$.

Mrozek, T., Poli, S., Sterlacchini, S., Zabuski, L., 2004. Landslide susceptibility assessment: a case study from Beskid Niski Mts., Carpathians, Poland. Polish Geological Institute Special Papers, 15: 13-18.

Mrozek, T., Kułak, M., Grabowski, D., Wójcik, A., 2014. Landslide Counteracting System (SOPO): Inventory database of landslide in Poland. Landslide Science for a Safer Geoenvironment, 2 : 815-820.

Pourghasemi, R.H., Mohammady, M., Pradhan, B., 2012. Landslide susceptibility mapping using index of entropy and conditional probability models in GIS: Safarood Basin, Iran. Catena, 97: 71-84.
Rączkowski, W., 2007. Landslide hazard in the Polish Flysch Carpathians. Studia Geomorphologica Carpatho-Balcanica, 41: 61-75.

Rączkowski, W., Mrozek, T., 2002. Activating of landsliding in the Polish Flysch Carpathians by the end of the 20th century. Studia Geomorphologica Carpatho-Balcanica, 36: 91-111.

Starkel, L., 2006. Geomorphic hazards in the Polish Flysch Carpathians. Studia Geomorphologica Carpatho-Balcanica, 40: 7-19.

Szczepanek, K., 2001. Late Holocene vegetation history in the Dukla Pass region (Low Beskidy, Carpathians) based on pollen and macrofossil analyses. Acta Palaeobotanica, 41: 341-353.

Ślączka, A., 1971. Geology of the Dukla Unit (in Polish with English summary). Prace Instytutu Geologicznego, 63: 1-77.

Urban, J., Margielewski, W., Žák, K., Hercman, H., Sujka, G., Mleczek, T., 2007. Calcareous speleothems in the pseudokarst Jaskinia Słowiańska-Drwali cave, Beskid Niski Mts., Poland. Nature Conservation, 63: 119-128.

Van Westen, C.J., 2004. Geo-information tools for landslide risk assessment: an overview of recent developments. In: Landslides: evaluation and stabilization (eds. W. Lacerda, M. Ehrlich, S.A.B. Fontoura and A.S.F. Sayao): 39-57. Taylor and Francis Group, Balkema, London. https://www.researchgate.net/publication/209805623

VIcko, J., Wagner, P., Rychlikova, Z., 1980. Evaluation of regional slope stability. Mineralia Slovaca, 12: 275-283.

Wdowiarz, S., Zubrzycki, A., Frysztak-Wołkowska, A., 1991. Detailed Geological Map of Poland, scale 1:50 000, sheet Rymanów (1040) (in Polish). Państwowy Instytut Geologiczny http://bazagis.pgi.gov.pl/website/cbdg/viewer.htm.

Wojciechowski, T., 2008a. Digital Elevation Model (DEM) in research of landslides (in Polish with English summary). Geo-Sympozjum Młodych Badaczy Silesia 2008 - Złoty Potok: 96-102. http://kgp.wnoz.us.edu.pl/pliki/File/tw_files/geosymp2008.pdf

Wojciechowski, T., 2008b. Podatność osuwiskowa zboczy w Wieliczce (in Polish). Prace Naukowe Instytutu Górnictwa Politechniki Wrocławskiej, 122: 247-256. http://kgp.wnoz.us.edu.pl/pliki/File/tw_files/Prezentacja_dokt2008.pdf.

Wójcik, A., 1997. Landslides in the Koszarawa drainage basin structural and geomorphological control (Western Carpathians, Beskid Żywiecki Mts.) (in Polish with English summary). Biuletyn Państwowego Instytutu Geologicznego, 376: 5-42.

Wójcik, A., 2003. Quaternary of the western part of the Jasło-Sanok Depression (Polish Outer Carpathians) (in Polish with English summary). Prace Państwego Instytutu Geologicznego, 178: $1-148$.

Wójcik, A., Zimnal, Z., 1996. Landslides along the San Valley between Bachórzec and Reczpol (the Carpathians, the Carpathian Foreland) (in Polish with English summary). Biuletyn Państwowego Instytutu Geologicznego, 374: 77-91.

Wójcik, A., Mrozek, T., Granoszewski, W., 2006. Lithological conditioning of landslides and climatic changes with examples from the Beskidy Mts., Western Carpathians, Poland. Geografia Fisica e Dinamica Quaternaria, 29: 197-209.

Zabuski, L., Thiel, K., Bober, L., 1999. Landslides in the Polish Carpathian flysch. Geology - Modelling - Stability calculations (in Polish with English summary). Wydawnictwo Instytutu Budownictwa Wodnego PAN, Gdańsk.

Zabuski, L., Wójcik, A., Gil, E., Mrozek, T., Rączkowski, W., 2009. Landslide processes in a flysch massif - case study of the Kawiory landslide, Beskid Niski Mts. (Carpathians, Poland). Geological Quarterly, 53 (3): 317-332.

Zuchiewicz, W., 1990. Morphological development of the Beskid Niski Mts. and Quaternary palaeogeography of the Polish Flysch Carpathians. Kwartalnik Geologiczny, 33 (3/4): 541-560. 